DE

M E D I C I N A

T R O P I C A L

$\mathrm{DE}$

SÃO PAULO

JOURNAL OF THE SÃO PAULO INSTITUTE OF TROPICAL MEDICINE

${ }^{1}$ Fundação Oswaldo Cruz (FIOCRUZ), Instituto Oswaldo Cruz (IOC), Laboratório de Hantaviroses e Rickettsioses, Rio de Janeiro, Rio de Janeiro, Brazil

${ }^{2}$ Fundação Oswaldo Cruz (FIOCRUZ), Escritório Técnico, Mato Grosso do Sul, Campo Grande, Brazil

${ }^{3}$ Fundação Oswaldo Cruz (FIOCRUZ), Instituto Oswaldo Cruz (IOC),

Laboratório de Vírus Respiratórios e do Sarampo, Rio de Janeiro, Rio de Janeiro, Brazil

${ }^{4}$ Fundação Oswaldo Cruz (FIOCRUZ), Departamento de Informações em Saúde, Centro de Informação Científica e Tecnológica, Rio de Janeiro, Rio de Janeiro, Brazil

Correspondence to: Tatiana Rozental Fundação Oswaldo Cruz (FIOCRUZ), Instituto Oswaldo Cruz (IOC), Laboratório de Hantaviroses e Rickettsioses, Av. Brasil, 4365, Manguinhos, CEP 21045-900, Rio de Janeiro, RJ, Brazil

Tel: +5521 25621873

E-mail: rozental@ioc.fiocruz.br

Received: 20 December 2017

Accepted: 23 March 2018

\section{Seroprevalence of Bartonella spp., Coxiella burnetii, and Hantavirus among people who inject drugs in Rio de Janeiro, Brazil: a retrospective assessment of a biobank}

\author{
Tatiana Rozental', Anamaria Szrajbman Vaz da Silva', Renata Carvalho de \\ Oliveira ${ }^{1}$, Alexsandra Rodrigues de Mendonça Favacho ${ }^{2}$, Maria de Lourdes \\ Aguiar Oliveira ${ }^{3}$, Francisco Inácio Bastos ${ }^{4}$, Elba Regina Sampaio de Lemos ${ }^{1}$
}

\section{ABSTRACT}

The increasing use of illicit drugs imposes a public health challenge worldwide. People who inject drugs (PWID) are more susceptible to health complications due to immunosuppression associated with drug use and non-hygienic self-administration of substances, contaminants, and liquids. PWID are subjected to increased risk of acquiring and transmitting different pathogens (frequently functioning as sentinel cases for (re)emerging pathogens), including those transmitted by arthropods and vertebrate reservoirs in unhealthy environments. A clear association between injection drug use and HIV, HBV, and HCV infections has been described; however, other infectious viral and bacterial agents have been seldomly assessed. In this study, we investigated the seroprevalence of Bartonella spp., Coxiella burnetii, and Hantavirus among 300 randomly selected PWIDs from Rio de Janeiro, as part of a multi-city cross-sectional study carried out in the 1990s. Point seroprevalences and respective 95\% CIs are as follows: $9.3 \%$ for C. burnetii (95\% CI: 6.0\%-13.0\%), 1.0\% for Bartonella spp. (95\% CI: $0.0 \%-3.0 \%$ ), and $4.0 \%$ for Hantavirus (95\% CI: $2.0 \%-7.0 \%$ ). In addition to the bloodborne pathogens, the results of this study increase our knowledge on other transmissible infectious agents in PWID. The high seroprevalence of C. burnetii and Hantavirus found among PWID is intriguing and suggests the need to carry out prospective studies, including molecular analyses, to confirm these findings and allow a better understanding of the putative relevance of these zoonotic infectious agents among PWID.

KEYWORDS: PWID (Persons who inject drugs). Intravenous drug user. Emergent infections. Bartonella spp. Coxiella burnetii. Hantavirus.

\section{INTRODUCTION}

Drug abuse is increasing worldwide, with approximately 87,000 associated deaths reported in $2014^{1}$. According to the World Drug Report ${ }^{1}$, there are more than 12 million People Who Inject Drugs (PWID) in the population aged 15-64 years old (a prevalence of $0.27 \% ; 0.19 \%-0.48 \%$ ) worldwide, predominantly in Eastern and Central Europe, as well as in certain areas of Southeast and Central Asia ${ }^{2}$. In these regions, the rate of injection drug use is 4.6 times higher than the world average ${ }^{1}$.

The implementation of measures to reduce drug-related harm, such as syringe exchange programs providing sterile syringes to PWIDs, condom distribution, hepatitis $\mathrm{B}$ virus (HBV) vaccination and treatment, have significantly decreased new HIV and hepatitis cases among PWID ${ }^{3}$ leading to a substantial decline in the number of new AIDS cases in this population between 2002 and 2016 according 
to the Brazilian Ministry of Health ${ }^{4}$. A decrease in the frequency of $\mathrm{HBV}$ and hepatitis $\mathrm{C}$ virus $(\mathrm{HCV})$ infections in PWID has also been described ${ }^{5-7}$. Altogether, these figures reinforce the success of harm reduction policies and the need to maintain and refocus them, considering the most at-risk subgroups and contexts.

Injection drug abuse usually takes place in scenarios of poor sanitation, with the presence of rodents, arthropods and vertebrate reservoirs for different zoonotic pathogens, in such a way that intravenous/subcutaneous ("skin popping") administration of non-sterile substances and syringe/needle sharing favor the recurring transmission of viral and bacterial infections ${ }^{8}$. Besides the most-frequently assessed infectious diseases in PWID, including HIV and hepatitis, other emerging and re-emerging infectious diseases prevalent among PWID, including tetanus, visceral leishmaniasis, and malaria, should be investigated and properly managed ${ }^{9-12}$. The injection of illicit drugs is important as an ecological niche and route for the worldwide diffusion of emerging blood-borne pathogens. Many PWID travel widely, including internationally. The international diffusion of PWID includes spreading pathogens to geographically different areas, leading to contact with reservoirs for emerging diseases. Infective endocarditis is another important and serious, potentially short-term lethal medical condition among PWID, and can be acquired through direct injection of the bacteria (Staphylococcus) or through secondary spread, via skin and soft tissue abscesses, into the bloodstream ${ }^{13-15}$.

Studies on C. burnetii, Bartonella, and Hantavirus infections among PWID are still scarce ${ }^{8,16-25}$ and are totally unavailable in Brazilian drug use scenarios.

Coxiella burnetii, the causative agent of $\mathrm{Q}$ fever, is transmitted to both humans and animals by the inhalation of aerosols or contaminated excreta such as milk, feces, urine, saliva and conception products (placenta, vaginal secretions, and amniotic fluid samples), derived from infected animals. Ticks are suspected of having a role in the transmission of the bacteria among wild vertebrates ${ }^{26}$. In Brazil, despite the existence of serologic evidence of Q fever since the 1950s, reports of this zoonosis have been rare, considering a timespan of almost seven decades ${ }^{27-34}$.

Bartonella spp. are intracellular hemotropic bacteria that grow fastidiously, transmitted by flea, lice and ticks bites in a range of mammalian hosts, including rodents, cats, dogs, humans, and bats ${ }^{35,36}$. These proteobacteria can be transmitted directly from a cat to humans during a scratch and less often by the bite of infected fleas in the case of Bartonella henselae. In Brazil, little information is available about the diversity of Bartonella. At present, B. henselae, $B$. quintana, B. clarridgeiae, B. vinsonii subsp. berkhoffii, and
B. vinsonii subsp. arupensis have been detected in human and animal populations $\mathrm{s}^{37-43}$.

Hantaviruses are spherical, enveloped RNA viruses classified into the Bunyaviridae family and are known to cause Hemorrhagic Fever with Renal Syndrome (HFRS) in Eurasia and Hantavirus Pulmonary Syndrome (HPS) in the American continent ${ }^{44,45}$. Human infection occurs by aerosol droplet of infected excrements or contact with contaminated rodent secretions ${ }^{46}$. In Brazil, HPS is an important public health issue and cases have been associated with six different genotypes - Anajatuba, Araraquara, Castelo dos Sonhos, Juquitiba, Laguna Negra, and Rio Mamore. Other hantaviruses - Jabora, Rio Mearim, and Seoul - were also detected in rodents, but have not yet been associated with HPS/HFRS ${ }^{44,45}$.

We investigated the prevalence of $C$. burnetii, Bartonella, and Hantavirus infections among 300 PWID, previously assessed by a cross-sectional multicity study conducted in Rio de Janeiro and two other sites in Brazil during 1999$2001^{6}$.

This information is valuable to warn policymakers and health professionals about infections that have been neglected by policies and initiatives that aimed to reduce drug-related harms and curb their spread.

\section{MATERIALS AND METHODS}

\section{PWID}

This is a retrospective assessment of a subsample from a cross-sectional multicity study conducted from 1999-2001. PWID were assessed in "drug scenarios" (public places, nightclubs and bars) of Rio de Janeiro, Brazil. The targeted communities were defined after a comprehensive effort of interviewing key informants and mapping drug scenarios from different communities using a brief ethnographic assessment, in-depth interviews, and focus groups, according to the World Health Organization (WHO) guidelines, after Watters and Biernacki's original contribution on targeted sampling procedures. New sampling methods that have been used in recent studies, such as respondent-driven sampling or time-location sampling, were virtually ignored in Brazil in that period and were introduced much later ${ }^{47}$.

The original database belongs to a large multicity study conducted in 13 cities, worldwide, entitled "Multicenter study of WHO-II, Brazil. Epidemiological survey - risk of HIV infection and viral hepatitis among drug users and transitions of cocaine use routes" under the coordination of Dr. Francisco I. Bastos and developed in the 1990s; this database was used in the present study for the analysis of 
a core set of original variables. A total of 300 biological samples, out of the existing 608 samples, were randomly selected with the help of the Epidemiological calculator (Epicalc R) version 2.15.1.0, taking into account the constraints secondary to high-cost laboratory inputs, as well as the necessary statistical power to carry out simple statistical tests for contingency tables.

\section{Ethics Statement}

The study was approved by the Institutional Review Board (IRB) of the Fundação Oswaldo Cruz (FIOCRUZ) after addition of tests for Bartonella spp, Coxiella burnetii, and Hantavirus infection (amendment). In accordance with ethical guidelines defined by National Commission for Research Ethics (CONEP), and international norms under the aegis of WHO regulations. Formal written consent forms were obtained from each adult individual (none of the participants were children; $>18$ years old - Brazilian national adult legal age), who was interviewed using a standardized questionnaire that included questions about socio-demographic status, pattern of injection drug use and sexual behavior.

Characterization of Coxiella, Bartonella, and Hantavirus infections

The presence of immunoglobulin $\mathrm{G}$ antibodies (IgG) against Coxiella burnetii and Bartonella spp. was determined by the indirect immunofluorescence assay (IFA), using commercial kits from Scimed $\mathrm{X}^{\circledR}$ (Dover, NJ, USA) and BION Enterprises ${ }^{\circledR}$ (Des Plaines, IL, USA), respectively ${ }^{48,49}$, in accordance with the manufacturer's instructions. Serum samples were screened at a 1:64 dilution and samples positive at 1:64 were further diluted and tested by IFA to determine the end titers. Negative and positive controls were included for each test run.

For Hantavirus investigation, IgG-ELISA was performed using a recombinant nucleocapsid protein from the Araraquara virus as the antigen, according to the protocol described by Figueiredo et al. ${ }^{50}$. Serum samples were screened at a 1:400 dilution and the sample was considered positive when the optical density (OD) was higher than 0.3. Negative and positive controls were included for each test run.

\section{Statistical analysis}

Statistical analysis was conducted with the help of Microsoft Office Professional Plus 2010 - Excel. Contingency table analysis (e.g., chi-square or Fisher's exact test and Student's $t$-test for means) were employed. Results were considered significant when $\mathrm{P}<0.05$.

Associations between the results of the serological tests and demographic (sex, ethnicity, education and place of residence) parameters as well as drug use variables (date of the first drug use, first injection, use of a previously used syringes and location where drug use took place) were analyzed in bivariate analyses.

\section{RESULTS}

The socio-demographic and drug use patterns of the 300 PWID included in the study are shown in Table 1 . The mean age was $31.7 \pm 10$ years (range 16-68 years).

Table 1 - Socio-demographic and drug use patterns in the population of people who inject drug (PWID), Rio de Janeiro, Brazil (1999-2001)

\begin{tabular}{|c|c|c|}
\hline Variables & & $\begin{array}{c}\text { Study population } \\
(300) \\
\mathrm{n}(\%)\end{array}$ \\
\hline Gender & $\begin{array}{c}\text { Male } \\
\text { Female }\end{array}$ & $\begin{array}{c}280(93.3) \\
20(6.7)\end{array}$ \\
\hline Age & $\begin{array}{c}<20 \\
20-29 \\
30-39 \\
40-49 \\
>49\end{array}$ & $\begin{array}{c}27(9.0) \\
119(39.7) \\
83(27.7) \\
58(19.3) \\
13(4.3)\end{array}$ \\
\hline Marital status & $\begin{array}{c}\text { Single } \\
\text { Living as married } \\
\text { Legally married } \\
\text { Legally separated } \\
\text { Divorced } \\
\text { Widowed }\end{array}$ & $\begin{array}{c}187(62.3) \\
50(16.7) \\
34(11.3) \\
19(6.3) \\
6(2.0) \\
4(1.3)\end{array}$ \\
\hline $\begin{array}{l}\text { Formal } \\
\text { education } \\
\text { (years) }\end{array}$ & $\begin{array}{c}0 \\
1-8 \\
9-12 \\
>12\end{array}$ & $\begin{array}{c}7(2.3) \\
130(43.3) \\
108(36.0) \\
55(18.3)\end{array}$ \\
\hline $\begin{array}{l}\text { How many times } \\
\text { injected in life }\end{array}$ & $\begin{array}{c}\text { Once } \\
2-9 \text { times } \\
10-99 \text { times } \\
100-999 \text { times } \\
1000 \text { or more times }\end{array}$ & $\begin{array}{c}10(3.3) \\
59(19.7) \\
115(38.3) \\
108(36.0) \\
8(2.7)\end{array}$ \\
\hline $\begin{array}{l}\text { How long } \\
\text { without } \\
\text { injecting } \\
\text { (months) }\end{array}$ & $\begin{array}{c}0 \\
1-11 \\
12-24 \\
>24\end{array}$ & $\begin{array}{l}69(23.0) \\
92(30.7) \\
53(17.7) \\
86(28.7)\end{array}$ \\
\hline
\end{tabular}

The average number of years of formal education was $9.4 \pm 4.2$ years (range $0-29$ years): $2.3 \%$ had no schooling at all, $52 \%$ had not completed the $1^{\text {st }}$ grade, $18 \%$ had completed the $1^{\text {st }}$ grade, $10.3 \%$ had not completed high school, $11 \%$ had completed high school and $6.3 \%$ had college degree. 
Regarding the level of education of the head of the family: $23 \%$ were illiterate or studied until the the $5^{\text {th }}$ grade; $36.7 \%$ studied beyond the $5^{\text {th }}$ grade, but did not complete the elementary school; $19.7 \%$ concluded the elementary school; $16.7 \%$ had completed high school; $2.7 \%$ had completed higher education and in $1.3 \%$ there was no information about the education level of the head of the family.

Most subjects (66.0\%) did not report any treatment for chemical dependency. Among those who had been previously treated for drug abuse $(34.0 \%)$, 39 were submitted to more than one treatment schedule. The most frequently reported approaches were admission to drug treatment clinics (49.7\%), support from mutual aid groups (18.6\%) and support from religious institutions (8.6\%). Overall, $44.7 \%(n=134)$ of the sampled PWID had been imprisoned at some point; among those, incarceration occurred once among $56 \%$ of the interviewees, twice among $20.9 \%$, three times among $17.9 \%$, and more than three times among 5.2\%. Among those arrested, $23.1 \%$ injected drugs inside jails/prisons, and $71 \%$ injected drugs with a previously used needle/syringe.

About half of the sampled PWID (53.7\%) started consuming drugs before they were 17 years old and the majority $(78.0 \%)$ reported using marijuana or hashish in the six months before the interview.

At the time of the study admission, the main route of drug use was: (i) non-injectable by $87.0 \%$ of the interviewees, (ii) injectable by $5.7 \%$, (iii) both routes by $4.3 \%$, and (iv) $3.0 \%$ refused to answer. A total of $23.0 \%$ had injected drugs in the month before the survey, $30.7 \%$ did not inject drugs for more than a month and less than a year before the survey and $46.3 \%$ did not inject drugs for more than one year.

\section{PWID and anti-Coxiella burnetii antibodies}

Point seroprevalence for C. burnetii was 9.3\% (28/300) (95\% CI: $6.0 \%-13.0 \%$ ). There were no statistically significant associations between the demographic or behavioral data and this biological outcome.

\section{PWID characteristics and anti-Bartonella spp. antibodies}

Point seroprevalence for anti-Bartonella spp. was $1.0 \%$ (3/300) (95\% CI: 0\%-3.0\%). All individuals were male, with incomplete elementary educationand did not report treatment for chemical dependency. At the time they were interviewed, two individuals reported previous noninjectable use of the same drug and to have used non-sterile injection equipment in their first episode of drug use.
Besides seropositivity for Bartonella, antibodies to Hantavirus and $C$. burnetii were also detected in a 29-year-old and a 43-year-old PWID, respectively. These very low figures preclude any further assessment of putative associations between socio-demographic and behavioral variables and these outcomes.

\section{PWID characteristics and anti-Hantavirus antibodies}

Anti-hantavirus point seroprevalence was 4.0\% (12/300) (95\% CI: 2.0\%-7.0\%). All individuals were male. The first illicit drug consumed was cocaine by another non-injectable route, with the exception of a 42-year-old individual, who had first injected amphetamine. The other subjects used cocaine as the first intravenous drug and 50\% used previously used syringes.

\section{DISCUSSION}

This was the first Brazilian seroprevalence study on C. burnetii, Bartonella, and Hantavirus exposure among PWID.

The demographic profile of the PWID population, composed mainly of young male adults with a low degree of formal education, was similar to those observed in previous reports $^{8,16,18,20,22,24,51,52}$.

We found a relatively high seroprevalence of $C$. burnetii in this population (9.3\%; 95\% CI: 6.0\%-13.0\%), almost twice the frequency found among non-PWID populations. Lamas et al..$^{53}$ found a seroprevalence of 3.2\% among HIV-positive patients from Rio de Janeiro, similar to the percentage (3.9\%) found in the general population of Minas Gerais ${ }^{37}$. The greater susceptibility of PWID to infectious agents due to non-hygienic injection practices, immunosuppression and sharing of injection paraphernalia, may explain these findings. It is likely that the lack of a detailed assessment of specific risk factors for these infections (the overall study targeted HIV and viral hepatitis) did not help in the effort to find statistically significant associations between socio-demographic and behavioral variables and $C$. burnetii infection.

In a Spanish study conducted in 590 PWID, a $C$. burnetii seroprevalence of $21.0 \%$ was reported ${ }^{21}$. This high frequency could be partially attributed to a lower definition of the IFA cutoff titer (1:16). If a cutoff point of 1:64 was used instead, as adopted in the present study, the reported seroprevalence would decrease to $14.6 \%$, in agreement with our study since the confidence intervals overlap. A second study was carried out in Italy, where Boschini et al. ${ }^{16}$ detected a seroprevalence of $33 \%$ (using the complement fixation test) after two outbreaks that 
occurred among residents in an agricultural community for the rehabilitation of drug users. It is pertinent to consider that, in this case, both methodological and epidemiological differences compromise comparative analyses.

There was no significant association between $C$. burnetti infection and socio-demographic variables. The seroprevalence of Bartonella infection was 1.0\%, far below that observed in other Brazilian seroepidemiological studies, as reported by Lamas et al. ${ }^{53}$ in blood banks from Rio de Janeiro (24.0\%) or among HIV-positive patients (38.4\%).

Although there are no Brazilian studies on Bartonella seroprevalence among PWIDs, six international studies show a high prevalence of anti-Bartonella antibodies in this population. In European studies, the prevalence is significantly higher in this population, compared to people who do not inject drugs. In Sweden, a prevalence of $39.0 \%$ was found among 59 PWID, in contrast to the $21.0 \%$ identified in the control group ${ }^{20}$; in Slovenia, these percentages were $43.0 \%$ vs. $25.0 \%$, respectively ${ }^{25}$. In two Spanish studies, the seroreactivities for Bartonella among PWID were $13.7 \%{ }^{24}$; and $24.2 \%{ }^{22}$, whereas in other two American studies, the seroprevalences were $47.5 \%$ and $37 \%$, respectively 8 .18. The discrepancies in Bartonella seroprevalence in PWID found in our study and in other international studies could be partially explained by the global differences in the geographical distribution of Bartonella species. The highest reported seropositivities were observed against $B$. elizabethae, followed by $B$. quintana, both considered non-existent and/or rarely detected in Brazil. In our study, the $B$. henselae antigen was used. Therefore, it is reasonable to speculate that if other Bartonella species were included in our assay, a different seroprevalence could be observed. Unfortunately, commercial kits that include other species than $B$. henselae are not available. Moreover, our sample included a low frequency of homeless PWID and about half of the subjects did not report to have injected drugs in the last year, in contrast with other studies. This could be explained by the route transition hypothesis ${ }^{54}$.

Hantavirus seroprevalence was $4.0 \%$, consistent with values found in other Brazilian studies, including 314 blood donors of Santa Catarina, a Southern State $(4.4 \%)^{55}$, and 1,063 individuals from the South and Southeast regions, including residents of rural areas, harbor employees and leptospirosis patients $(3.0 \%)^{56}$. These samples are likely to contain the hantavirus genotype of Seoul, identified in the 1980s in the North of Brazil, for which urban rats (Rattus norvegicus) are reservoirs ${ }^{57}$.

Although reference serological tests for the detection of Q fever (97.7\% sensitivity and $100 \%$ specificity), bartonellosis ( $97.4 \%$ sensitivity and $100 \%$ specificity), and HPS/HCPS (97,2\% sensitivity and $100 \%$ specificity) were used in the present study, we cannot rule out the possibility of cross-reactivity with other infectious agents; however, our results were based on $\operatorname{IgG}$ detection, which is less prone to low specificity than IgM detection.

Additional studies on bartonellosis, including detection of a range of different bacterial species, would be valuable to assess comparable seroprevalences in different geographical regions. The high seroprevalence of $C$. burnetii among PWID must be highlighted and reinforces the need for further prospective studies, including serological and molecular analyses, to confirm these first findings and to allow a better understanding of the importance of $\mathrm{Q}$ fever among this population. This paper highlights the findings of a targeted surveillance of a highly vulnerable population. This study has been carried outwith the double purpose of identifying "sentinel populations", as well as the effort to discern the putative bridging between vulnerable populations with other populations or the general population at large.

\section{CONFLICT OF INTERESTS}

The authors declare that they have no conflict of interest or disclosures concerning this work.

\section{ACKNOWLEDGMENTS}

This research received financial support of National Council for Scientific and Technological Development (CNPq), grant $\mathrm{N}^{\circ} 407664 / 2012$, besides the financial support of Foundation for Research of Rio de Janeiro State (FAPERJ) grant $\mathrm{N}^{\circ} \mathrm{E}-26 / 010.001567 / 2014$. This study used a database and samples collected for the project entitled "WHO Drug Injection Study Phase II" and was approved, after an amendment, by the Ethics Committee of the Oswaldo Cruz Institute in 2015.

\section{REFERENCES}

1. United Nations Office on Drugs and Crime. World drug report 2016. New York: UNODC: 2016. [cited 2017 Aug 16]. Available from: https://www.unodc.org/doc/wdr2016/ WORLD_DRUG_REPORT_2016_web.pdf

2. El-Bassel N, Strathdee SA, El Sadr WM. HIV and people who use drugs in Central Asia: confronting the perfect storm. Drug Alcohol Depend. 2013;132 Suppl 1:S2-6.

3. Bastos FI. Structural violence in the context of drug policy and initiatives aiming to reduce drug-related harm in contemporary Brazil: a review. Subst Use Misuse. 2012;47:1603-10. 
4. Brasil. Ministério da Saúde. Secretaria de Vigilância em Saúde. Departamento de Vigilância, Prevenção e Controle das Infecções Sexualmente Transmissíveis, do HIV/Aids e das Hepatites Virais. Boletim epidemiológico HIV AIDS 2017. Brasília; Ministério da Saúde; 2017. [cited 2018 Mar 27]. Available from: http://www.aids.gov.br/pt-br/pub/2017/ boletim-epidemiologico-hivaids-2017

5. Fonseca EM, Ribeiro JM, Bertoni N, Bastos FI. Syringe exchange programs in Brazil: preliminary assessment of 45 programs. Cad Saude Publica. 2006;22:761-70.

6. Oliveira SA, Hacker MA, Oliveira ML, Yoshida CF, Telles PR, Bastos FI. A window of opportunity: declining rates of hepatitis $B$ virus infection among injection drug users in Rio de Janeiro, and prospects for targeted hepatitis B vaccination. Rev Panam Salud Publica. 2005;18:271-7.

7. Oliveira ML, Yoshida CF, Telles PR, Hacker MA, Oliveira SA, Miguel JC, et al. Trends in HCV prevalence, risk factors and distribution of viral genotypes in injecting drug users: findings from two cross-sectional studies. Epidemiol Infect. 2009;137:970-9.

8. Comer JA, Diaz T, Vlahov D, Monterroso E, Childs JE. Evidence of rodent-associated Bartonella and Rickettsia infections among intravenous drug users from Central and East Harlem, New York City. Am J Trop Med Hyg. 2001;65:855-60.

9. Amela C, López-Gay D, Alberdi JC, Castilla J. Injecting drug use as risk factor for visceral leishmaniasis in AIDS patients. Eur J Epidemiol. 1996;12:91-2.

10. Bastos FI, Telles PR, Castilho EA, Barcellos CA. A epidemia de AIDS no Brasil. In: Minayo MC, organizadora. Os muitos Brasis: saúde e população na década de 80. São Paulo: Hucitec; 1995. p.245-68.

11. De Jarlais DC, Stimson GV, Hagan H, Friedman SR. Injection drug use and emerging blood-borne diseases. JAMA. 1996;276:1034.

12. Rezza G, Pizzuti R, De Campora E, De Masi S, Vlahov D. Tetanus and injections drug use: rediscovery of a neglected problem? Eur J Epidemiol. 1996;12:655-6.

13. Asgeirsson $\mathrm{H}$, Thalme A, Weiland O. Low mortality but increasing incidence of Staphylococcus aureus endocarditis in people who inject drugs: experience from a Swedish referral hospital. Medicine (Baltimore). 2016;95:e5617.

14. Axelsson A, Søholm H, Dalsgaard M, Helweg-Larsen J, Ihlemann N, Bundgaard H, et al. Echocardiographic findings suggestive of infective endocarditis in asymptomatic Danish injection drug users attending urban injection facilities. Am J Cardiol. 2014;114:100-4.

15. Wurcel AG, Anderson JE, Chui KK, Skinner S, Knox TA, Snydman DR, et al. Increasing infectious endocarditis admissions among young people who inject drugs. Open Forum Infect Dis. 2016;3:ofw157.

16. Boschini A, Di Perri G, Legnani D, Fabbri P, Ballarini P,
Zucconi R, et al. Consecutive epidemics of Q fever in a residential facility for drug abusers: impact on persons with human immunodeficiency virus infection. Clin Infect Dis. 1999;28:866-72.

17. Chmielewski T, Podsiadły E, Tylewska-Wierzbanowska S. Presence of Bartonella spp. in various human populations. Pol J Microbiol. 2007;56:33-8.

18. Comer JA, Flynn C, Regnery RL, Vlahov D, Childs JE. Antibodies to Bartonella species in inner-city intravenous drug users in Baltimore, Md. Arch Intern Med. 1996;156:2491-5.

19. Khabbaz RF, Ksiazek TG, Caiaffa WT, Rollin PE, Taylor E, Vlahov D. Seoul hantavirus seropositivity among injecting drug users in Baltimore. J Infect Dis. 1994;170:1636-7.

20. McGill S, Rajs J, Hjelm E, Lindquist O, Friman G. A study on forensic samples of Bartonella spp. antibodies in Swedish intravenous heroin addicts. APMIS. 2003;111:507-13.

21. Montes M, Cilla G, Marimon JM, Diaz de Tuesta JL, PerezTrallero E. Coxiella burnetii infection in subjects with HIV infection and HIV infection in patients with Q fever. Scand J Infect Dis. 1995;27:344-6.

22. Pons I, Sanfeliu I, Nogueras MM, Sala M, Cervantes M, Amengual MJ, et al. Seroprevalence of Bartonella spp. infection in HIV patients in Catalonia, Spain. BMC Infect Dis. 2008;8:58.

23. Que YA, Moreillon P. Infective endocarditis. Nat Rev Cardiol. 2011;8:322-36.

24. Ramos AJ, Vargas J, Fernández-Rivera J, Macías J, Mira JA, Pineda JA. Prevalencia de seropositividad para Bartonella spp. en pacientes adictos a drogas por vía parenteral infectados y no infectados por el virus de la inmunodeficiencia humana. Med Clin (Barc). 2002;119:565-7.

25. Zupan S, Poljak M, Avsic-Zupanc T. Prevalence of Bartonella infections in Slovenian intravenous drug users. Ann NY Acad Sci. 2003;990:414-8.

26. Porter SR, Czaplicki G, Mainil J, Guattéo R, Saegerman C. Q Fever: current state of knowledge and perspectives of research of a neglected zoonosis. Int J Microbiol. 2011;2011:248418.

27. Borges DR. Evidência sorológica de febre Q em carneiros do Brasil. Rev Paul Med. 1962;60:424-32.

28. Brandão H, Valle LA, Christóvão DA. Investigações sobre a febre "Q" em São Paulo. I. Estudo sorológico em operários de um frigorífico. Arq Fac Hig Saúde Pública Univ Sao Paulo 1953;7:127-34.

29. Epelboin L, Nacher M, Mahamat A, Pommier de Santi V, BerliozArthaud A, Eldin C, et al. Q Fever in French Guiana: tip of the iceberg or epidemiological exception? PLoS Negl Trop Dis. 2016;10:e004598.

30. Lemos ER, Rozental T, Mares-Guia MA, Almeida DN, Moreira N, Silva RG, et al. Q fever as a cause of fever of unknown origin and thrombocytosis: first molecular evidence of Coxiella burnetii in Brazil. Vector Borne Zoonotic Dis. 2011;11:85-7. 
31. Mares-Guia MA, Rozental T, Guterres A, Ferreira MS, Botticini $\mathrm{RG}$, Terra AK, et al. Molecular identification of $\mathrm{Q}$ fever in patients with a suspected diagnosis of dengue in Brazil in 2013-2014. Am J Trop Med Hyg. 2016;94:1090-4.

32. Valle LA, Bassoi ON, Castro RM, Ferreira JM. Febre Q em São Paulo: primeiro caso confirmado por estudos sorológicos. Rev Paul Med. 1955;46:447-56.

33. Rozental T, Mascarenhas LF, Rozenbaum R, Gomes R, Mattos GS, Magno CC, et al. Coxiella burnetii, the agent of Q fever in Brazil: its hidden role in seronegative arthritis and the importance of molecular diagnosis based on the repetitive element IS1111 associated with the transposase gene. Mem Inst Oswaldo Cruz. 2012;107:695-7.

34. Travassos J, Ubatuba A, Silva N, Mello MT. Febre Q no Rio de Janeiro. Ci Cult. 1954;6: 199-200.

35. Chomel BB, Kasten RW. Bartonellosis, an increasingly recognized zoonosis. J Appl Microbiol. 2010;109:743-50.

36. Harms A, Dehio C. Intruders below the radar: molecular pathogenesis of Bartonella spp. Clin Microbiol Rev. 2012;25:42-78.

37. Costa PS, Brigatte ME, Greco DB. Antibodies to Rickettsia rickettsii, Rickettsia typhi, Coxiella burnetii, Bartonella henselae, Bartonella quintana, and Ehrlichia chaffeensis among healthy population in Minas Gerais, Brazil. Mem Inst Oswaldo Cruz. 2005;100:853-9.

38. Diniz PP, Maggi RG, Schwartz DS, Cadenas MB, Bradley JM, Hegarty B, et al. Canine bartonellosis: serological and molecular prevalence in Brazil and evidence of co-infection with Bartonella henselae and Bartonella vinsonii subsp. berkhoffii. Vet Res. 2007;38:697-710.

39. Favacho AR, Andrade MN, de Oliveira RC, Bonvicino CR, D’Andrea PS, de Lemos ER. Zoonotic Bartonella species in wild rodents in the state of Mato Grosso do Sul, Brazil. Microbes Infect. 2015;17:889-92.

40. Gonçalves LR, Favacho AR, Roque AL, Mendes NS, Fidelis Júnior OL, Benevenute JL, et al. Association of Bartonella species with wild and synantropic rodents in different Brazilian biomes. Appl Environ Microbiol. 2016;82:7154-64.

41. Pitassi LH, Diniz PP, Scorpio DG, Drummond MR, Lania BG, Barjas-Castro ML, et al. Bartonella spp. bacteremia in blood donors from Campinas, Brazil. PLoS Negl Trop Dis. 2015;9:e0003467.

42. Rozental T, Ferreira MS, Guterres A, Mares-Guia MA, Teixeira BR, Gonçalves J, et al. Zoonotic pathogens in Atlantic Forest wild rodents in Brazil: Bartonella and Coxiella infections. Acta Trop. 2017;168:64-73.

43. Diniz PP, Velho PE, Pitassi LH, Drummond MR, Lania BG, Barjas-Castro ML, et al. Risk factors for Bartonella species infection in blood donors from Southeast Brazil. PLOS Negl Trop Dis. 2016;10:e004509.
44. Guterres A, de Oliveira RC, Fernandes J, Schrago CG, de Lemos ER. Detection of different South American hantaviruses. Virus Res. 2015;210:106-13.

45. de Oliveira RC, Guterres A, Fernandes J, D’Andrea PS, Bonvicino CR, de Lemos ER. Hantavirus reservoirs: current status with an emphasis on data from Brazil. Viruses. 2014;6:1929-73.

46. Manigold T, Vial P. Human hantavirus infections: epidemiology, clinical features, pathogenesis and immunology. Swiss Med Wkly. 2014;144:w13937.

47. Barbosa Júnior A, Pascom AR, Szwarcwald CL, Kendall C, McFarland W. Transfer of sampling methods for studies on most-at-risk populations (MARPs) in Brazil. Cad Saude Publica. 2011;27 Suppl 1:S36-44.

48. Dupont HT, Thirion X, Raoult, D. Q Fever serology: cutoff determination for microimmunofluorescence. Clin Diagn Lab Immunol. 1994;1:189-96.

49. La Scola B, Raoult D. Laboratory diagnosis of rickettsioses: current approaches to diagnosis of old and new rickettsial diseases. J Clin Microbiol. 1997;35:2715-27.

50. Figueiredo LT, Moreli ML, Borges AA, de Figueiredo GG, Badra SJ, Bisordi I, et al. Evaluation of an enzyme-linked immunosorbent assay based on Araraquara virus recombinant nucleocapsid protein. Am J Trop Med Hyg. 2009;81:273-6.

51. Capistrano FC, Ferreira AC, Silva TL, Kalinke LP, Maftum MA. Perfil sociodemográfico e clínico de dependentes químicos em tratamento: análise de prontuário. Esc Anna Nery. 2013;17:234-41.

52. Horta RL, Horta BL, Rosset AP, Horta CL. Perfil dos usuários de crack que buscam atendimento em Centros de Atenção Psicossocial. Cad Saude Publica. 2011;27:2263-70.

53. Lamas CC, Mares-Guia MA, Rozental T, Moreira N, Favacho AR, Barreira J, et al. Bartonella spp. infection in HIV positive individuals their pets and ectoparasites in Rio de Janeiro, Brazil: Serological and molecular study. Acta Trop. 2010;115:137-41.

54. Bridge J. Route transition interventions: potential public health gains from reducing or preventing injecting. Int J Drug Policy. 2010;21:125-8.

55. Cordova CM, Figueiredo LT. Serologic survey on hantavirus in blood donors from the state of Santa Catarina, Brazil. Rev Inst Med Trop Sao Paulo. 2014;56:277-9.

56. Iversson LB, da Rosa AP, Rosa MD, Lomar AV, Sasaki MG, Le Duc JW. Infecçäo humana por Hantavirus no sul e sudeste do Brasil. Rev Assoc Med Bras (1992). 1994;40:85-92.

57. Le Duc JW, Smith GA, Pinheiro FP, Vasconcelos PF, Rosa ES, Maiztegui JI. Isolation of Hantaan-related virus from Brazilian rats and serologic evidence of its widespread distribution in South America. Am J Trop Med Hyg. 1985;34:810-5. 